\title{
Treatment of digital ulcers in systemic sclerosis: Case series study of thirteen patients and discussion on outcome
}

\author{
Yahia Abuowda ${ }^{1,2 *}$, Raquel Sousa Almeida ${ }^{1,2}$, Ana Alves Oliveira ${ }^{1,2}$, Petra Pego ${ }^{1,2}$, Cristina Santos ${ }^{1,2,3}$, João Matos-Costa ${ }^{1,2,3}$ \\ ${ }^{1}$ Clinic of autoimmune diseases, Department of Internal Medicine - III, Hospital Distrital de Santarém, Santarém, Portugal \\ ${ }^{2} \mathrm{NEDAI}$ - Group of Systemic Autoimmune Diseases of the SPMI - Sociedade Portuguesa de Medicina Interna, Lisboa, Portugal \\ ${ }^{3}$ DUO Registry Center - The Digital Ulcers Outcome Registry Center D0489, Santarém, Portugal
}

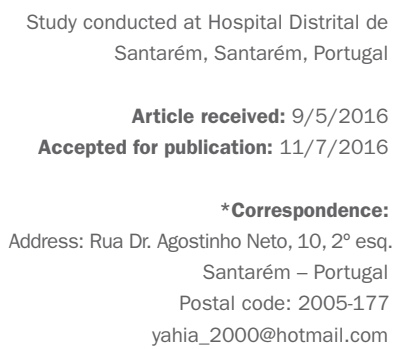

\section{SUMMARY}

Introduction: In systemic sclerosis (SSc), digital ulcers (DU) are debilitating and recurrent. They are markers of prognosis and are associated with disability and mortality. Treatment strategies have been developed to block the proposed mechanisms of this complication.

Objective: Clinical description of a population of SSc patients with DU, treatment, complications and outcome.

Method: Analysis of 48 SSc patients meeting 2013 ACR-EULAR criteria, followed between 1999-2015; 13 patients had DU. Treatment protocol applied included cycles of 21 days of alprostadil, which can be repeated in the absence of DU healing. After DU healing, bosentan was initiated.

Results: DU healing was achieved with intravenous prostanoid in 12 patients; seven patients required repeated treatment for DU healing. Twelve patients were later treated with bosentan; three of them experienced recurrence of DU, while one was anti-B2-GPI positive. Four patients had soft tissue loss and three other suffered digital amputation, these being late diagnosis.

Conclusion: Younger patients and early referrals had better outcomes. Endothelin receptor antagonist toxicity should be monitored, particularly in patients previously exposed to hepatotoxic drugs.

Keywords: systemic sclerosis, digital ulcers.

\section{INTRODUCTION}

Systemic sclerosis (SSc) is a rare and progressive disease that affects the connective tissue. It is characterized by a diffuse vasculopathy that is accompanied by cutaneous and visceral fibrosis. Digital ulcers (DU) are one of the main complications derived from SSc-associated microvasculopathy, which is recurrent and incapacitating. They occur in $30 \%$ of patients with limited SSc and $58 \%$ in diffuse forms. ${ }^{1-3}$

Its etiology is multifactorial; however, two triggers have been described as responsible for the development of DU: one is related to the structure of the vascular wall, which leads to a proliferation of the intima and an increased production of vasoconstrictors; the other is related to the existence of a variable degree of intraluminal thrombosis. ${ }^{1,46}$

Among the mechanisms considered to be responsible for the development of DU, endothelial injury results from a decrease in the caliber of the intravascular lumen caused by the secretion of collagen and other components of the extracellular matrix, which in turn leads to fibroblast activation, hindering blood flow and causing chronic ischemia of tissues. Endothelial injury is accompanied by increased levels of endothelin-1 (ET-1), a potent vasoconstrictor peptide. The actions of ET- 1 are mediated by two types of receptors: endothelin type A (ETa) and type B (ETb). Activation of type A leads to vasoconstriction and vascular remodeling, whereas type B leads to vasodilation. This leads to an imbalance between the production of vasoconstricting (ET-1) and vasodilating (prostacyclin and nitric oxide) substances. ${ }^{3,4,7,8}$

Another proposed mechanism is the presence of autoantibodies that produce direct damage on endothelial cells. Secondarily, platelet activation occurs by the release of thromboxane and then intraluminal thrombosis. $3,4,7,8$ 
The treatment of DU was developed from the blockade of these proposed etiopathogenic principles, ${ }^{1,4-6}$ which are inseparable from those that contribute to Raynaud's phenomenon, since both constitute a similar microvascular dysfunction occurring at different stages. Standard treatment is described in evidence-based European clinical practice guidelines, and there is a need for systematic and rigorous research to better define and structure new treatments for this complication. ${ }^{9}$

The results of previous studies suggest that intermittent cycles of iloprost improve the progression of DUs and prevent new episodes of digital ischemia. Also, treatment with endothelin receptor antagonists (bosentan) may have some efficacy in preventing new DUs as well as in improving the functionality of the hand. ${ }^{2}$

The objective of our review is to describe a population of patients with SSc and DU, their treatment, complications and clinical results, implementing the protocol of our Center.

\section{Method}

A case series including 48 patients with SSc, of whom thirteen had associated DU. In the sample studied, there was a predominance of the female sex $(69 \%)$, and the mean age was 61.8 years ranging between 49 and 81 years (Table 1). The DUs presented by all included patients were distal or cardinal. They were followed between 1999 and 2015, in a doctor's office for Autoimmune Diseases, in our area of influence (which covers about 200,000 inhabitants). All of them met the criteria of the ACREULAR 2013 classification. ${ }^{3,10}$

The protocol applied included 21-day cycles of daily $60 \mathrm{mcg}$ of alprostadil (the only prostacyclin available in our Center) that could be repeated if there was no scarring. In response, bosentan was initiated in increasing doses, starting with $62.5 \mathrm{mg}$ twice daily up to $125 \mathrm{mg}$ twice daily. After completing each cycle of alprostadil, patients were referred to the Day Hospital for observation, and in the case of those who were treated with bosentan, the control was performed every three months in the Specialty Consultation. As a defining characteristic of clinical improvement of the DU, the following elements were considered: decrease in extension, absence of inflammation, healing and absence of recurrence.

The clinical records, data from the Computer Registry of Autoimmune Diseases of Portugal (RIDAI) and the international registry DUO (Digital Ulcers Outcome) were reviewed. Statistical analysis was performed using Microsoft Excel $2007^{\circledR}$, after obtaining Informed Patient Consent.

\section{ResULtS}

Thirteen patients with SSc and DU (Figure 1) were diagnosed, of whom twelve had a form of limited SSc, and four also had associated calcinosis.

Regarding markers, anticentromere antibodies (ACA) were positive in ten patients, anti-B2-GPI in two, other two had anti-Ro/SSA and anti-La/SSB, and anti-Scl 70 was found in one case. It should be noted that a single case that was diagnosed with diffuse SSc was ACA positive without anti-Scl-70 positivity. Antiphospholipid antibodies (APLA) were investigated in nine of the cases, with two being positive.

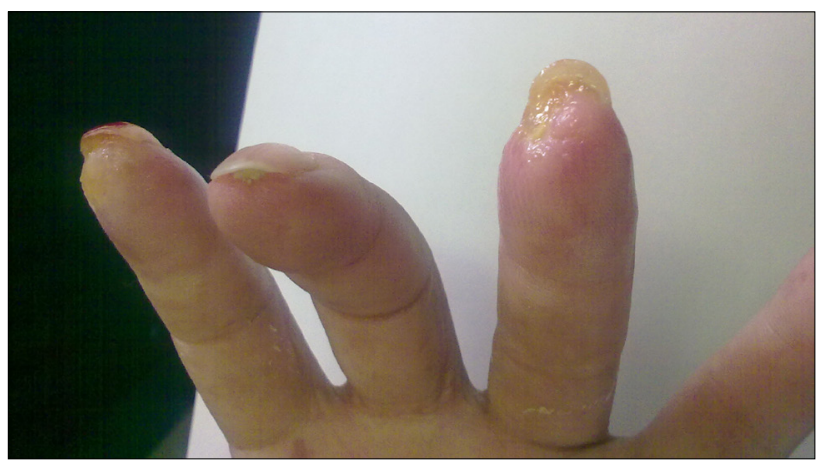

FIGURE 1 Example of digital ulcers in the left hand of patient number 4 prior to treatment with bosentan.

All patients were medicated with calcium channel antagonists (CCA) for Raynaud's phenomenon. Healing was achieved with prostanoids in twelve of the patients in the first cycle, with a need to repeat treatment in seven of them. Twelve subsequently underwent treatment with bosentan (Figure 2), with one case of recurrence of DU in three of them, one of which was anti-B2-GPI positive.

There was also recurrence of DU in a patient who had not yet started treatment with bosentan due to a delay in medication approval and dispensing.

After healing, there was residual Raynaud's phenomenon in six patients, with a need to adjust vasodilator therapy in all of them.

An alteration of the liver enzymes was observed in four patients, persisting in one individual with a history of alcoholism and relapsing DU, and therefore the treatment with bosentan was stopped.

In three patients there was previous exposure to methotrexate, with normalization of the transaminase values after taking folinic acid.

Eleven patients were medicated with antiplatelet agents and four with oral anticoagulants, two of them 


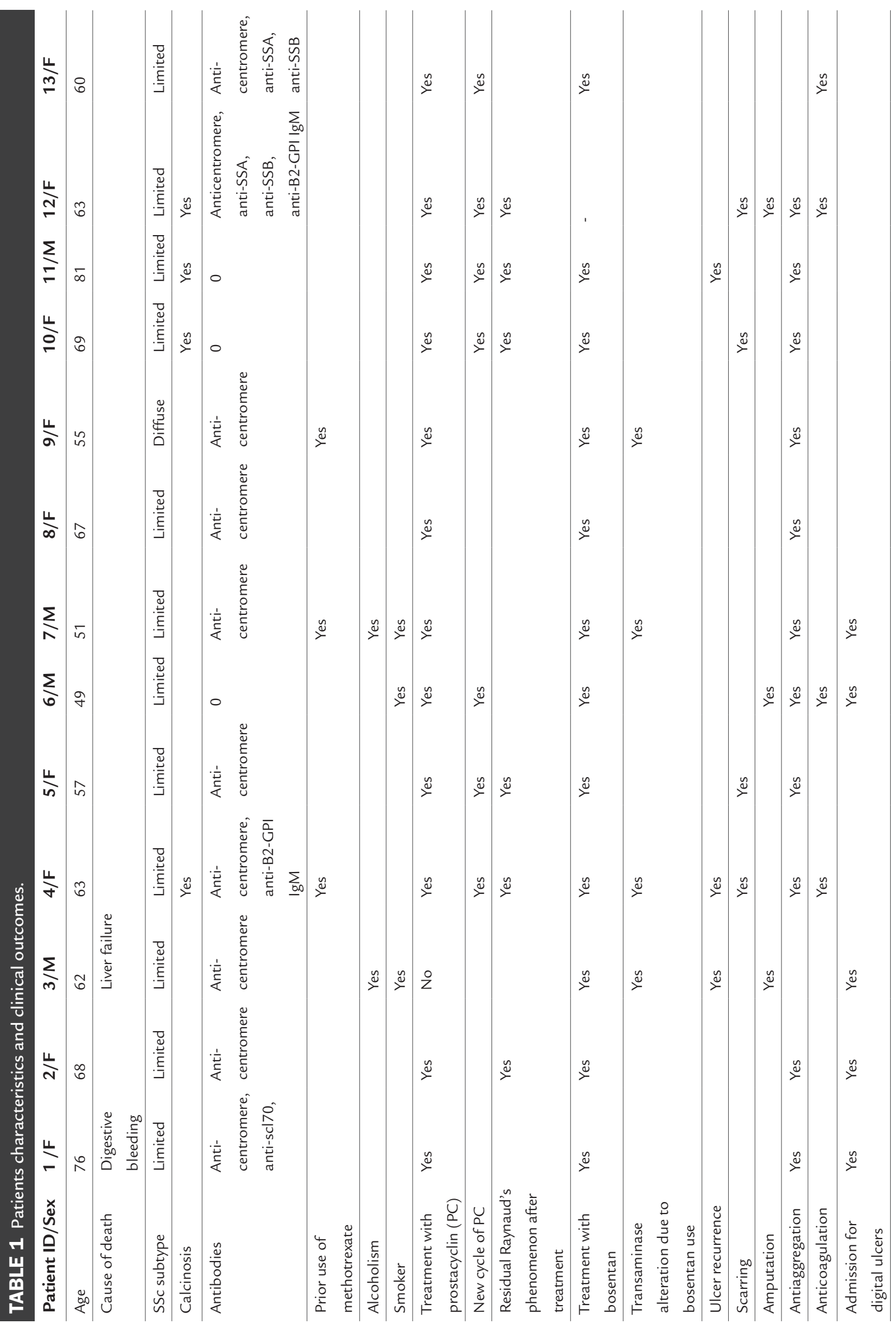



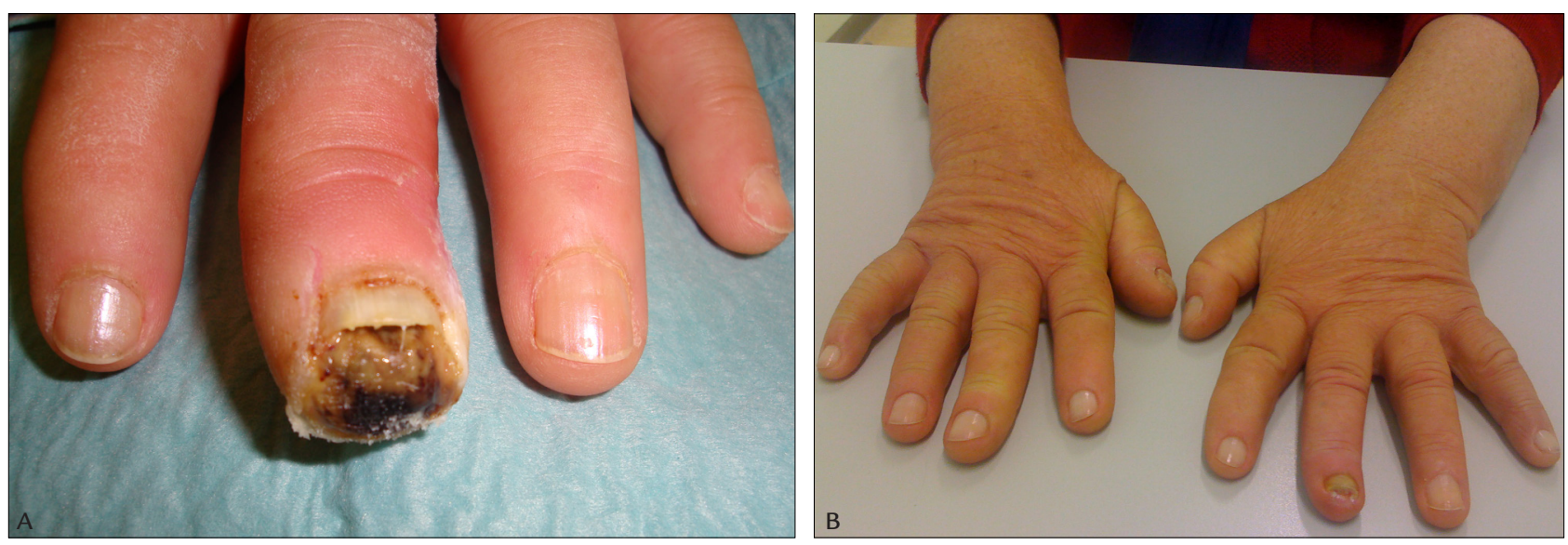

FIGURE 2 Digital ulcer of the third finger of the left hand with loss of substance in patient number 10, prior to treatment $(A)$ and after treatment (B).

were anti-B2-GPI positive, with an improvement in the healing process. Two patients were already anticoagulated, one of them due to pulmonary hypertension prior to the diagnosis of SSc and another because of the presence of mitral valve prosthesis.

Four patients had scarring, and digital amputation was necessary in three other cases that were diagnosed very late (one of them had actually undergone the procedure before the diagnosis of SSc).

Two patients died, one of liver failure and the other of digestive hemorrhage. Three patients remained active and only one of the eleven retired due to peripheral vasculopathy.

\section{Discussion}

DUs are a prognostic marker of SSc, which is associated with functional disability of the hand, leading to a lower quality of life and greater morbidity and mortality.,11

The treatment of DU involves screening for complications, promoting healing and preventing recurrences. Optimal treatment is a challenge and includes nonpharmacological, pharmacological and surgical measures. The intravenous use of CCAs and prostanoids has a high level of scientific evidence. ${ }^{9}$ Endothelin receptor antagonists are approved for the prevention of DU recurrence with improved hand functionality and better functional and vital prognosis based on the results of the RAPIDS- 1 and RAPIDS- 2 trials. ${ }^{2,4,6,12,13}$ Other studies have shown that bosentan treatment increased the fingertip blood flow in patients with low perfusion in its initial stages, helping in the process of remodeling the capillary microcirculation. ${ }^{2,5}$

Short-acting antiplatelet and anticoagulant therapy should be considered, although there is no strong evidence of its efficacy. ${ }^{4}$ There is strong theoretical support for the use of antiplatelet agents in SSc and a consensus on the practical approach for prescription, being recommended in all patients with chronic digital ischemia. ${ }^{4,14}$

The role of statins is noteworthy, as they have proven useful in some studies for increasing the levels of nitric oxide and reducing ET-1. This improvement in endothelial dysfunction may be attributable to its anti-inflammatory and immunomodulatory properties. ${ }^{4}$ The benefit of long-term anticoagulation is probably achieved in patients with APLA and severe or recurrent digital ischemia., ${ }^{4,1}$

\section{Conclusion}

In this small series, the most favorable progression was observed in young patients, which we admit is due to early diagnosis and beginning of the treatment. Conversely, the evolution was unfavorable in older patients, with prolonged disease progression, late diagnosis and presence of lesion in a target organ.

It was necessary to monitor the toxicity of endothelin receptor antagonists in individuals previously exposed to alcohol and hepatotoxic drugs, which may require discontinuation of bosentan.

Treatment with bosentan helped to prevent recurrences with new ulcers, but a significant number of patients presented residual Raynaud's phenomenon, leading to a necessary intensification of vasodilating therapy. In the treatment of DU, one always has to resort to several drugs simultaneously or sequentially, always looking for a synergy. ${ }^{15}$ Registering information is essential for further progress in this area, to increase available evidence.

\section{Conflict of interest}

The authors declare no conflict of interest. 


\section{Resumo}

Tratamento de úlceras digitais na esclerose sistêmica: série de casos de 13 doentes e análise crítica dos resultados

Introdução: As úlceras digitais (UD) são complicações incapacitantes e recorrentes, associadas a menor qualidade de vida e maior mortalidade na esclerose sistêmica (ES). O tratamento baseia-se em antagonizar os mecanismos fisiopatológicos em causa.

Objetivo: Descrever uma amostra de doentes com diagnóstico de ES e UD, o tratamento, as complicações e os resultados clínicos.

Método: Série de 48 casos diagnosticados com ES, critérios de classificação ACR-EULAR 2013, seguidos entre 1999 e 2015, dos quais 13 apresentavam UD. O protocolo aplicado incluía ciclos de 21 dias de alprostadil podendo ser repetidos no caso de não existir cicatrização. Nos casos em que houve cicatrização foi iniciado bosentano. Resultados: No tratamento das UD, 12 doentes realizaram prostaciclina endovenosa, com necessidade de tratamentos repetidos em sete doentes. Doze doentes foram posteriormente tratados com bosentano, com recorrência de UD em três doentes, um deles com presença de anti-B2-GPI. Quatro doentes ficaram com cicatrizes e em três houve amputação digital, sendo casos de diagnóstico tardio.

Conclusão: Os doentes mais jovens tiveram melhores resultados, possivelmente em razão de melhorias globais nos cuidados de saúde prestados e de referenciação precoce. A toxicidade dos antagonistas dos receptores da endotelina deve ser monitorizada, sobretudo em doentes com exposição prévia a drogas hepatotóxicas.

Palavras-chave: esclerose sistêmica, úlceras digitais.

\section{References}

1. LeRoy EC, Medsger TA Jr. Criteria for the classification of early systemic sclerosis. J Rheumatol. 2001; 28(7):1573-6.

2. Meijs J, Voskuyl AE, Bloemsaat-Minekus JP, Vonk MC. Blood flow in the hands of predefined homogeneous systemic sclerosis population: the presence of digital ulcers and improvement with bosentan. Rheumatology (Oxford). 2015; 54(2):262-9.

3. Valentini G, Marcoccia A, Cuomo G, Iudici M, Vettori S. The concept of early systemic sclerosis following 2013 ACR $\backslash$ EULAR criteria for the classification of systemic sclerosis. Curr Rheumatol Rev. 2014; 10(1):38-44

4. Herrick AL. The pathogenesis, diagnosis and treatment of Raynaud phenomenon. Nat Rev Rheumatol. 2012;8(8):469-79.

5. Guiducci S, Bellando Randone S, Bruni C, Carnesecchi G, Maresta A, Iannone $\mathrm{F}$, et al. Bosentan fosters microvascular de-remodelling in systemic sclerosis. Clin Rheumatol. 2012; 31(12):1723-5.

6. Cutolo M, Zampogna G, Vremis L, Smith V, Pizzorni C, Sulli A. Longterm effects of endothelin receptor antagonism on microvascular damage evaluated by nailfold capillaroscopic analysis in systemic sclerosis. J Rheumatol. 2013; 40(1):40-5.

7. Dumoitier N, Lofek S, Mouthon L. Pathophysiology of systemic sclerosis: state of the art in 2014. Presse Med. 2014; 43(10 Pt 2):e267-78.

8. Bakst R, Merola JF, Franks AG Jr, Sanchez M. Raynaud phenomenon: pathogenesis and management. J Am Acad Dermatol. 2008; 59(4):633-53.

9. Kowal-Bielecka O, Landewé R, Avouac J, Cwiesko S, Minati I, Cziejak L, et al. EULAR recommendations for the treatment of systemic sclerosis: a report from the EULAR Scleroderma Trials and Research group (EUSTAR). Ann Rheum Dis. 2009; 68(5):620-8.

10. van den Hoogen F, Khanna D, Fransen J, Johnson SP, Baron M, Tyndall A, et al. 2013 Classification criteria for systemic sclerosis: an ACR/EULAR collaborative initiative. Ann Rheum Dis. 2013; 72(11):1747-55.

11. Vitiello M, Abuchar A, Santana N, Dehesa L, Kardel F. An update of the treatment of cutaneous manifestations of systemic sclerosis. The dermatologist's point of vie. J Clin Aesthet Dermatol. 2012; 5(7):33-43.

12. Korn JH, Mayes M, Matucci Cerinic MM, Rainisio M, Pope J, Hachulla E, et al. Digital ulcers in systemic sclerosis: prevention by treatment with bosentan, an oral endothelin receptor antagonist. Arthritis Rheum. 2004; 50(12):3985-993.

13. Matucci-Cerinic MM, Denton CP, Furst DE, Mayes MD, Hsu VM, Carpentier $\mathrm{P}$, et al. Bosentan treatment of digital ulcers related to systemic sclerosis: results from the RAPIDS-2 randomised, double-bilnd, placebo-controlled trial. Ann Rheum Dis. 2011; 70(1):32-8,

14. Chatterjee S. Management of Raynaud's phenomenon in the patient with connective tissue disease. Curr Treat Options Cardiovasc Med. 2010; 12(2):185-204

15. Nihtyanova SI, Ong VH, Denton CP. Current management strategies for systemic sclerosis. Clin Exp Rheumatol. 2014; 32(2 Suppl 81):156-64. 